\title{
Sensitive and Selective Extraction-Free Spectrophotometric Assay of Chloroquine Phosphate in Pharmaceuticals Based on Ion-Pair Reaction with Bromocresol Green and Bromocresol Purple
}

\author{
Nagib Qarah AS, Basavaiah $\mathrm{K}^{*}$ and Swamy $\mathbf{N}$ \\ Department of Chemistry, University of Mysore, Manasagangothri, Mysuru-570006, Karnataka, India
}

*Corresponding author: Basavaiah K, Department of Chemistry, University of Mysore, Manasagangothri, Mysuru-570006, Karnataka, India, Tel: 9448939105/0821-2419659; Fax: 0091-821-2421263; E-mail: kanakapurabasavaiah@gmail.com

Received date: February 22, 2017; Accepted date: March 20, 2017; Published date: March 22, 2017

Copyright: @ 2017 Nagib Qarah AS, et al. This is an open-access article distributed under the terms of the Creative Commons Attribution License, which permits unrestricted use, distribution, and reproduction in any medium, provided the original author and source are credited.

\begin{abstract}
Chloroquine Phosphate (CQP) is an antimalarial agent extensively used in the treatment of malaria. Two spectrophotometric methods, which are rapid, simple, selective and sensitive, are presented for the determination of $\mathrm{CQP}$ in bulk and dosage forms using two sulphonphthalein dyes: Bromocresol Green (BCG method) and Bromocresol Purple (BCP method). The methods are based on the formation of chloroform-soluble ion-pairs, when CQP is reacted with either dye, suitable for measurement at $420 \mathrm{~nm}$ in both the methods. The effects of reaction time, dye concentration and reaction medium were carefully studied and optimized. Under the optimum reaction conditions, Beer's law is obeyed overconcentration ranges 1-20 and 0.5-12 $\mu \mathrm{gL} \mathrm{m}^{-1} \mathrm{CQP}$ (base) for BCG method and BCP method respectively, with corresponding molar absorptivity values of $1.79 \times 10^{4}$ and $3.09 \times 10^{4} \mathrm{~L} \mathrm{~mol}^{-1}$ $\mathrm{cm}^{-1}$. The calculated limits of detection (LOD) and quantification (LOQ) are 0.27 and $0.82 \mu \mathrm{g} \mathrm{mL}-1$ (BCG method); 0.15 and $0.46 \mu \mathrm{g} \mathrm{mL}^{-1}$ (BCP method). Intra-day and inter-day \%RSD values were $\leq 1.56 \%$ and $\leq 1.83 \%$ whereas the respective \%RE values were better than $2 \%$. Robustness of the methods was determined by performing analysis with slightly altered optimum conditions while ruggedness was tested by inter-personnel as well as inter-equipment variations; the \%RSD values were within the accepted limits in both instances. Method selectivity was as ascertained by placebo blank and synthetic mixture analysis with no detectable interference from co-formulated substances in the assays. The methods were applied to the determination of CQP in tablets, suspension and injections with satisfactory results. Accuracy was also confirmed by recovery test via standard-addition procedure.
\end{abstract}

Keywords: Chloroquine phosphate; Assay; Spectrophotometry; Dyes; Ion-pair; Pharmaceuticals

\section{Introduction}

Chloroquine Phosphate (CQP) is chemically known as 7chloro-4[[4-(diethylamino)-1-methylbutyl]amino]quinoline phosphate, a 4 -aminoquinolein antimalarial drug. It is the prototype synthetic antimalarial drug most widely used to treat all types of malarial infections. The drug is also prescribed to decrease the symptoms of rheumatoid arthritis and to treat systemic and discoid lupus erythematosus in adults [1-3]. bCPQ is official in the US pharmacopeia, which contains a uv-spectrophotometric method [2]. In the open literature, few methods are found for the determination of CQP in pharmaceuticals and include titrimetry [4-6], gravimetry [7], potentiometry [8-11], spectrofluorimetry [12-17], uvspectrophotometry [18-21], HPLC [22-32], HPTLC [26] and bioassay [33].

As visible spectrophotometric methods offer significant advantages over the reported methods with respect to selectivity and sensitivity [4-7], simplicity and ease of performance [8-33] and cost-effectiveness [11-32], several such methods have been developed for the determination of CQP in pharmaceuticals. The drug has been determined as chloroform/methylene chloride-soluble ion-pair with and dyes such as bromocresol purple [34], Rose Bengal [35], wool fast blue and bromocresol green [36], complexes formed at acidic $\mathrm{pH}$ buffers were extracted into suitable organic solvents and measured at wavelengths of maximum absorption. Ion-pairs formed with complex ions such as, $\left[\mathrm{Co}(\mathrm{SCN})_{4}\right] 2-[37],\left[\mathrm{Mo}(\mathrm{SCN})_{6}\right]-[38]$ were extracted into organic solvent and measured, serving as basis of assay of CQP. Methods based on measurement of chare-transfer complexes formed by the drug with chloranilic acid [39], iodine and 2,3-dichloro-5,6dicyano-p-benzoquinone (DDQ) [40] in polar organic solvents have been published by several researchers. The yellow coloured product resulting from bromination of CQP with bromate-bromide mixture [41] in acid medium was also used for the determination of CQP. Measurement of orange-red coloured ferroin, formed as a result of redox-complexation reactions involving CQP, iron (III) and 1,10phenanthroline, has also been employed for the quantification of CQP by visible spectrophotometry [42]. It was also determined by kinetic spectrophotometry [43] using bromate and iodate as oxidimetric agents.

However, many of these methods suffer from limitations and include low sensitivity [39,41], narrow linear range [34], $\mathrm{pH}$ dependency, use of tedious and time-consuming step, extraction step [34,36] and/or longer contact time [41]. Therefore, need for simple, facile, and easy to perform spectrophotometric methods for the determination of CQP in pharmaceuticals was strongly felt. Previously, BCP [34] and BCG [36] have been used as ion-pair agents for the spectrophotometric determination of CQP. However, these procedures are tedious and time consuming since the ion-pair formed at a specific $\mathrm{pH}$ in aqueous medium need to be extracted and less accurate due to possible incomplete recovery of analyte from the aqueous phase methods based on the measurement of ion-pairs bromocresol purple 
Citation: Nagib Qarah AS, Basavaiah K, Swamy N (2017) Sensitive and Selective Extraction-Free Spectrophotometric Assay of Chloroquine Phosphate in Pharmaceuticals Based on Ion-Pair Reaction with Bromocresol Green and Bromocresol Purple. Pharm Anal Acta 8: 539. doi:10.4172/2153-2435.1000539

Page 2 of 9

(BCP method) in chloroform, without involving extract step. The new methods exhibited advantageous features with respect to sensitivity, linear range, speed and ease of performance compared to the existing methods.

\section{Experimental}

\section{Apparatus}

A Systronics model 166 digital spectrophotometer (Systronics, Ahmedabad, and Gujarat, India) with matched $1 \mathrm{~cm}$ quartz cells was used for absorbance measurements.

\section{Reagents and materials}

The chemicals used were of analytical-reagent grade, and spectroscopic-grade organic solvents were used in the assay. Chloroformic solutions of bromocresol green (BCG) and Bromocresol Purple (BCP) (both from Loba Chemie Ltd., Mumbai, India; both $0.05 \%)$ were prepared.

High purity chloroquine phosphate (99.95\%) was procured from Cipla India Ltd., Mumbai, India, and used as received. Cadiquin 200 mg (Zydus Cadila Healthcare Ltd., Bangalore, India), Maliago $500 \mathrm{mg}$ (Cipla Ltd., Bangalore, India) tablets; Cloquin $40 \mathrm{mg} / \mathrm{mL}$ injection (Indoco Remedies Ltd., Baddi, India) and Emquin $160 \mathrm{mg} / 10 \mathrm{~mL}$ suspension (Merck Biopharm India) were purchased from local market.

\section{Preparation of chloroquine base $(\mathrm{CQB})$ solution}

An amount of chloroquine phosphate CQP equivalent to $10 \mathrm{mg}$ CQB was dissolved in about $20 \mathrm{~mL}$ of water and $\mathrm{pH}$ of aqueous solution was raised to about $9.5-10$ by adding $5 \mathrm{~mL}$ of $1 \mathrm{M} \mathrm{NaOH}$ solution. CQB formed was extracted by shaking with $4 \times 10 \mathrm{~mL}$ portions of chloroform; extracts were passed over anhydrous sulphate and collected in a dry $50 \mathrm{~mL}$ volumetric flask. The extracts were made up to the mark with chloroform and mixed. The resulting $200 \mu \mathrm{g} \mathrm{mL}^{-1}$ CQB solution was diluted to 40 and $20 \mu \mathrm{g} \mathrm{mL}^{-1}$ levels with chloroform.

\section{Procedures}

\section{Procedure for bulk drug}

Preparation of calibration graphs: BCG method: Aliquots (0.25-5.0 $\mathrm{mL}$ ) of $40 \mu \mathrm{g} \mathrm{mL}-1$ CQB solution were transferred accurately into several $10 \mathrm{~mL}$ volumetric flasks and added $2 \mathrm{~mL}$ of $0.05 \%$ BCG solution to each flask. The contents were diluted to the mark with chloroform and absorbance of each solution measured at $420 \mathrm{~nm}$ vs the blank, after 5 min.

BCP method: Different volumes, from 0.25 to $6.0 \mathrm{~mL}$, of $20 \mu \mathrm{g} \mathrm{mL}-1$ CQB solution were accurately measured and placed in $10 \mathrm{~mL}$ volumetric flasks. Two $\mathrm{mL}$ of $0.05 \%$ BCP solution were added to each flask and the contents diluted to the mark with chloroform, and absorbance measured after $5 \mathrm{~min}$ at $420 \mathrm{~nm}$ against the reagent blank.

In each case, calibration curve was prepared by plotting absorbance vs concentration, and concentration of the unknown was deduced from the regression equation derived from Beer's law data.

\section{Procedure for dosage forms}

Tablets: An amount of pulverized chloroquine phosphate tablets equivalent to $10 \mathrm{mg}$ of chloroquine base was accurately weighed. Into a $50 \mathrm{~mL}$ stoppered flask and shaken with $20 \mathrm{~mL}$ water for $20 \mathrm{~min}$. to extract the active content to the aqueous phase, the contents were filtered using a quantitative filter paper. The resulting filtrate and washings were quantitatively transferred into a $125 \mathrm{~mL}$ separating funnel and then treated exactly as described under preparation of standard base solution. Tablet extract containing $200 \mu \mathrm{g} \mathrm{mL}^{-1} \mathrm{CQB}$ was diluted to 40 and $20 \mu \mathrm{g} \mathrm{mL}^{-1}$ levels and assayed in five replicates by 2 $\mathrm{mL}$ and $3 \mathrm{~mL}$ aliquots, respectively, by BCG method and BCP method.

Injection: Aliquot of injectable product equivalent to $20 \mathrm{mg}$ Chloroquine base was transferred accurately to a $125 \mathrm{~mL}$ separating funnel containing $10 \mathrm{~mL}$ of water and then steps described under preparation of standard solution were followed. After diluting this solution $\left(200 \mu \mathrm{g} \mathrm{mL}^{-1}\right)$ to 40 and $20 \mu \mathrm{g} \mathrm{mL}^{-1}$ levels, general procedures were applied.

Suspension: Five $\mathrm{mL}$ of suspension containing $80 \mathrm{mg}$ CQP was diluted accurately with water to $50 \mathrm{~mL}$ in a calibration flask. An aliquot of diluted suspension (containing $10 \mathrm{mg}$ CQB) was transferred into a $125 \mathrm{~mL}$ separating funnel containing $10 \mathrm{~mL}$ water, the salt was converted to base and finally extracted as chloroformic solution as described earlier. The extract was diluted with chloroform and subjected to analysis following the general procedure.

\section{Procedure for placebo and synthetic mixture}

A placebo blank of the composition: $25 \mathrm{mg}$ sucrose, $10 \mathrm{mg}$ talc, 15 mg lactose, $20 \mathrm{mg}$ starch, $10 \mathrm{mg}$ gelatin, $20 \mathrm{mg}$ magnesium stearate, 25 $\mathrm{mg}$ sodium alginate and $25 \mathrm{mg}$ methyl cellulose was prepared by homogeneous mixing in a mortar. $10 \mathrm{mg}$ of placebo was placed in a 50 $\mathrm{mL}$ calibration flask and its extract prepared as described under "procedure for tablets". Two $\mathrm{mL}$ of the extract was subject to analysis following the general procedures. To $10 \mathrm{mg}$ of the placebo blank prepared above, CQP equivalent to $10 \mathrm{mg}$ CQB was added, mixed thoroughly and the mixture was quantitatively transferred into a $50 \mathrm{~mL}$ stoppered bottle; and then steps described under "procedure for tablets" were followed.

\section{Procedure for stoichiometric relationship}

Job's method of continuous variations of equimolar solutions was employed. CQB and dye solutions (BCG or BCP) equivalent to $3.75 \times$ $10^{-5} \mathrm{M}$ each were prepared in chloroform. CQB and BCG or BCP solutions mixed in complementary ratios keeping the total volume at $10 \mathrm{~mL}$, and the absorbance was measured at $420 \mathrm{~nm}$. A plot of absorbance versus mole fraction of the drug was prepared in each case.

\section{Procedures for method validation}

The assay validation procedures were carried out according to current ICH guidelines [44], and the validation parameters included linearity, the Limits of Detection (LOD), Limits of Quantification (LOQ), precision, accuracy, robustness, ruggedness, selectivity and accuracy by recovery test.

\section{Linearity}

The linearity was assessed by the calibration graph, which was constructed by plotting the absorbance $(\mathrm{Y})$ versus concentration of 
Citation: Nagib Qarah AS, Basavaiah K, Swamy N (2017) Sensitive and Selective Extraction-Free Spectrophotometric Assay of Chloroquine Phosphate in Pharmaceuticals Based on Ion-Pair Reaction with Bromocresol Green and Bromocresol Purple. Pharm Anal Acta 8: 539. doi: $10.4172 / 2153-2435.1000539$

Page 3 of 9

CQB (X) and the regression equation was calculated. The LOD and LOQ were calculated using the formulae:

$$
L O D=\frac{3 S}{k} \text { and } L O D=\frac{10 S}{k}
$$

Where $\mathrm{S}$ is the standard deviation of the replicate blank absorbance values and $\mathrm{k}$ is the slope of the calibration curve. The Beer's law range, the regression equation, LOD, LOQ, molar absorptivity and Sandell sensitivity values are computed in Table 1.

\section{Accuracy and precision}

The accuracy of the methods was determined on the basis of the difference in mean calculated and amount/concentration taken $(\%$ deviation from the actual concentration, DFA); and the precision was determined by calculating the intra-day and inter-day relative standard deviation. These were computed by analyzing standard solution of CQB at three levels seven times on the same day (intra-day) and on five consecutive days (inter-day). The results of this study expressed as relative error (\%RE) and relative standard deviation (\%RSD) are presented in Table 2.

\section{Robustness and ruggedness}

Robustness was evaluated by assaying the standard solutions after slight but deliberate variations in the analytical conditions like contact time and volume of dyes. Ruggedness, on the other hand, was assessed by a study in which the determination was performed by three analysts and also by a single analyst using three different instruments in the same laboratory and also by three analysts using a single instrument. The results of this study reported as intermediate precision and expressed as \%RSD are computed in Table 3.

\section{Selectivity}

The placebo blank and synthetic mixtures were analyzed by the developed methods and the results compared with those obtained on standard drug solution.

\section{Application to formulations}

Pharmaceutical formulations solution prepared as described earlier was objected to analysis by applying the developed procedures by taking $3 \mathrm{~mL}$ in five replicates, and the measured analytical signal was used to calculate the percent of the label claim. For comparison, the pharmaceutical formulations extract in chloroform were applied the assay by reference method [2]. These finding along with the results of statistical tests are given in Table 4.

\section{Recovery test}

Pre-analyzed tablet powder was spiked with pure drug at three levels and the total quantity of the drug was calculated, and finally the percent recovery of the pure drug added was arrived at. The results obtained by this test are found in Table 5 .

\section{Results and Discussion}

$\mathrm{CQB}$, being a basic nitrogen-containing compound, reacts instantly with BCG and BCP in chloroform, giving characteristic yellow coloured products which exhibit an absorption maximum at $420 \mathrm{~nm}$ (Figure 1). The coloured species can be attributed the formation of ionpair complex between the drug and the dye. The yellow colour is thought to be the result of the proton transfer from the acidic dye to the basic centre of the drug. Subsequently the dye is converted to an open quinoidal yellow-coloured anion [45-51]. The latter forms an ionpair with the drug cation. The possible reaction pathway is shown in (Figure $2 \mathrm{a}$ and $2 \mathrm{~b}$ ).

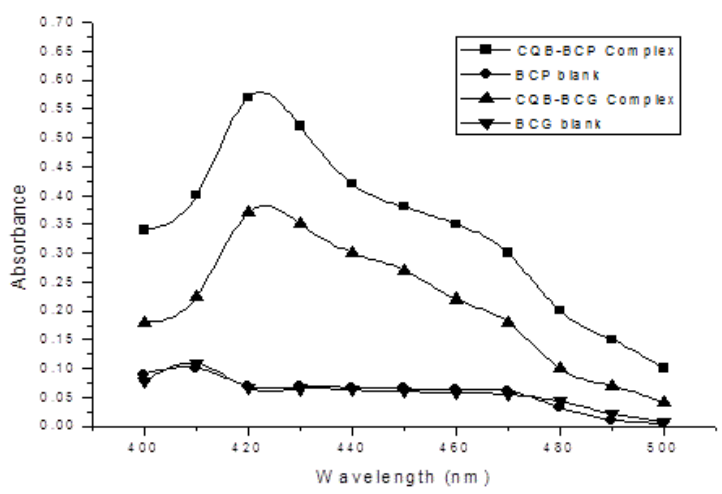

Figure 1: Absorption spectra of CQB-BCG and CQB-BCP complexes $\left(8 \mu \mathrm{g} \mathrm{mL}^{-1}\right)$ and their blank.

\section{Method development}

Optimization of experimental variables: The spectrophotometric properties of colored ion-pair complexes as well as various experimental variables affecting complex formation were carefully studied and optimized to determine the most favorable conditions of assay. All the reactions were studied as a function of reaction medium, reagent volume and reaction time.

Reaction medium: A number of organic solvents such as chloroform, methylene chloride, dichloroethane, carbon tetrachloride, xylene, hexane, etc. were tried as the reaction medium. Chloroform was selected as the ideal medium since it yielded maximum sample absorbance and minimum blank absorbance.

Standing time and stability: The optimum reaction time was investigated from 0.5 to $5 \mathrm{~min}$ after mixing the reactants at room temperature $\left(29 \pm 2^{\circ} \mathrm{C}\right)$. Full colour development was realized almost instantaneously. However, measurement in each instance was made after $5 \mathrm{~min}$ to ensure quantitative complexation. The complexes were stable for 1 and $4 \mathrm{~h}$ in BCG method and BCP method, respectively.

Effect of dye concentration: The effect of dye concentration on the intensity of the formed yellow coloured ion-pair complexes at the selected wavelengths was tested by measuring the absorbance of solutions containing a constant amount of CQB $\left(8 \mu \mathrm{g} \mathrm{mL}^{-1}\right.$ in both method) and different volumes $(0.5-3.0 \mathrm{~mL})$ of dyes. Maximum color intensity of ion-pair was achieved at $2.0 \mathrm{~mL}$ in each method (Figure 2). A slight increase in blank absorbance was observed in both methods at larger dye volumes. 
Citation: Nagib Qarah AS, Basavaiah K, Swamy N (2017) Sensitive and Selective Extraction-Free Spectrophotometric Assay of Chloroquine Phosphate in Pharmaceuticals Based on Ion-Pair Reaction with Bromocresol Green and Bromocresol Purple. Pharm Anal Acta 8: 539. doi: $10.4172 / 2153-2435.1000539$

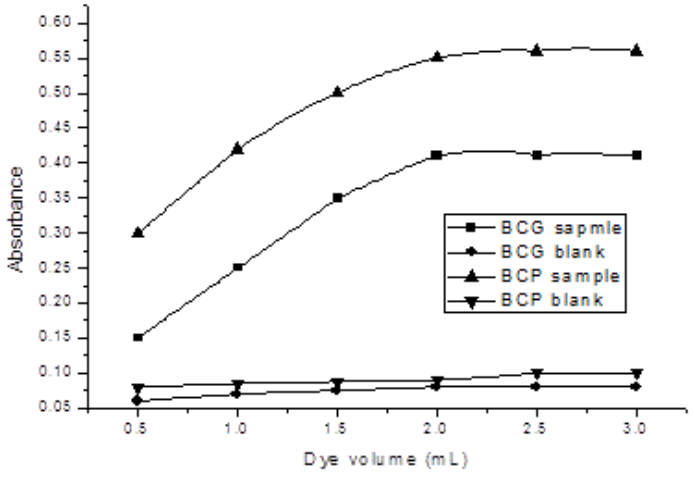

Figure 2: Effect of dye concentration $\left(8 \mu \mathrm{g} \mathrm{mL}^{-1} \mathrm{CQB}\right.$ in both methods).

Stoichiometry: Job's method continuous variations for establishing the reaction stoichiometry revealed that the reaction between chloroquine $(\mathrm{CQB})$ and the two dyes $\mathrm{BCG}$ and $\mathrm{BCP}$, was found to proceed with a ratio of $1: 2$ (drug: dye), which it is in agreement with the reaction scheme suggested in Figures $3 \mathrm{a}$ and $3 \mathrm{~b}$.

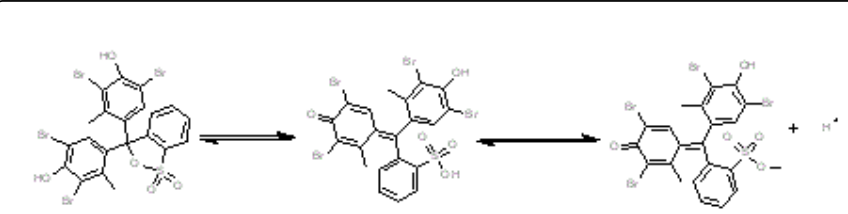

BCG (lactoid ring) quinoid ring deprotonated dye<smiles>[CH][N+](CC)(CC)CCCC(C)Nc1cc[n+]([O-])c2cc(Cl)ccc12</smiles>
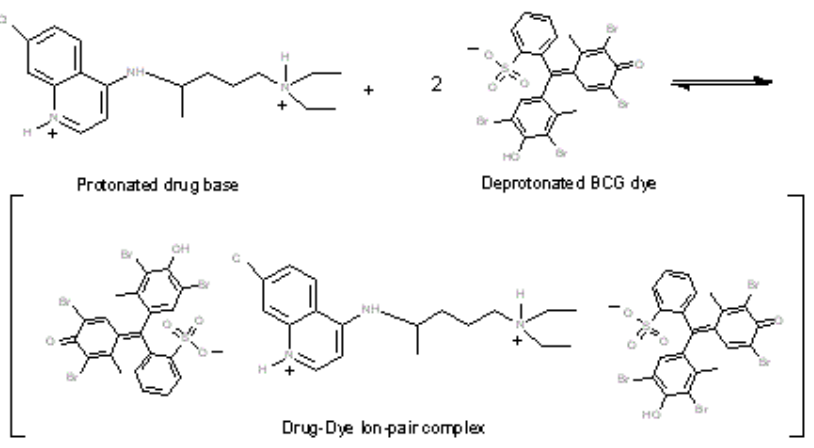

Figure 3a: The possible reaction pathway for the formation of CQBBCG ion-pair complex.

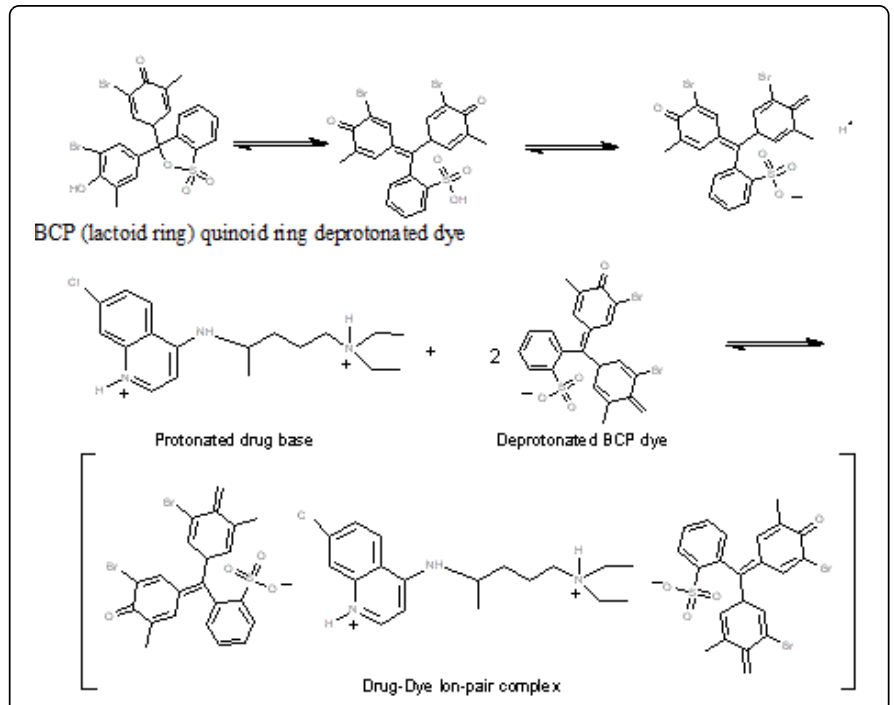

Figure 3b: The possible reaction pathway for the formation of CQBBCP ion-pair complex.

Method validation: The proposed methods were validated for linearity, sensitivity, accuracy, precision, and selectivity (Figures $4 \mathrm{a}$ and $4 b)$.

Linearity and sensitivity: Typical calibration data for the methods were obtained from linear regression analysis of absorbanceconcentration data. Beer's law plots were linear over the ranges 1-20 and $0.5-12 \mu \mathrm{g} \mathrm{mL}^{-1}$ for BCG method and BCP method, respectively. The regression parameters and sensitivity indices are computed in Table 1.

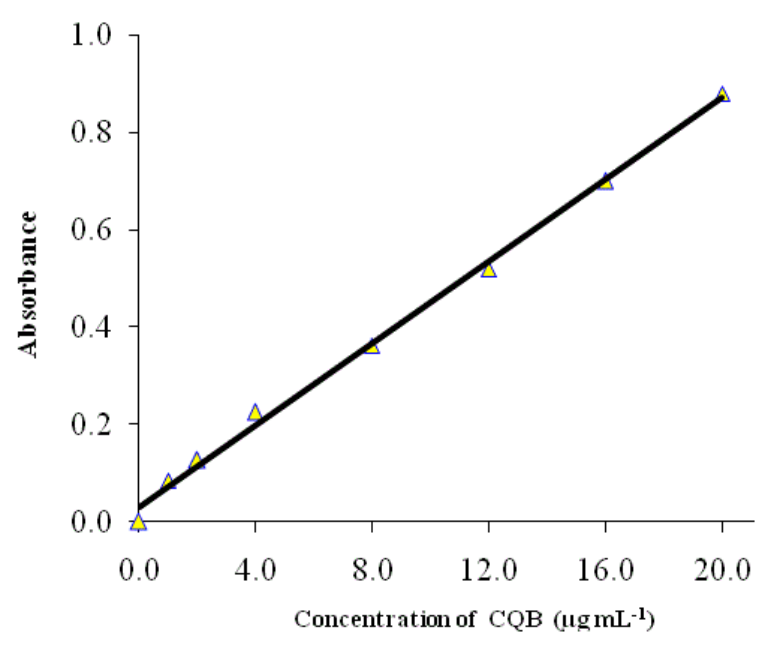

Figure 4a: Calibration curve for BCG method. 
Citation: Nagib Qarah AS, Basavaiah K, Swamy N (2017) Sensitive and Selective Extraction-Free Spectrophotometric Assay of Chloroquine Phosphate in Pharmaceuticals Based on Ion-Pair Reaction with Bromocresol Green and Bromocresol Purple. Pharm Anal Acta 8: 539. doi: $10.4172 / 2153-2435.1000539$

Page 5 of 9

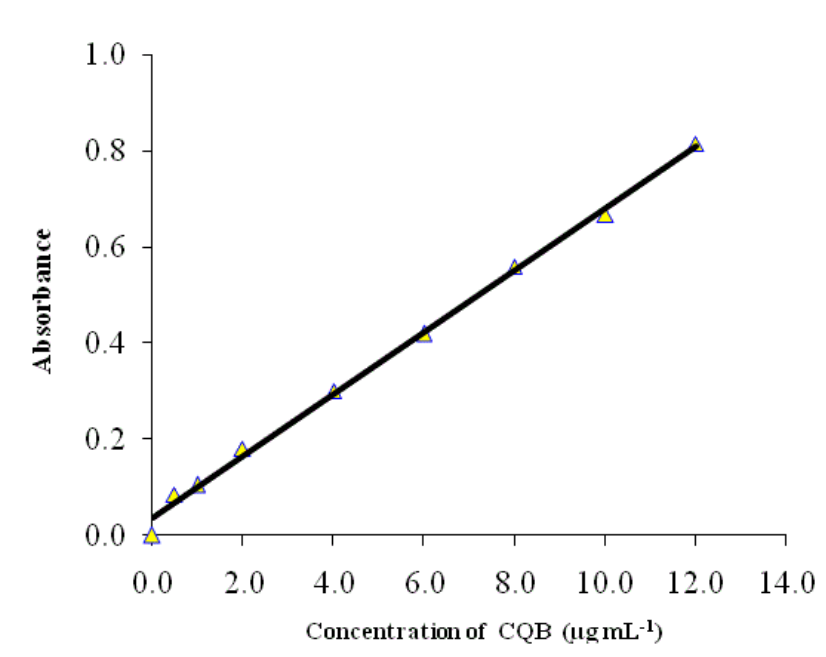

Figure 4b: Calibration curve for BCP method.

\section{Precision and accuracy}

To determine the precision and accuracy of the methods, standard CQB solutions at three concentration levels, were assayed seven times on the same day and five times each on five successive days. Table 2 show the \%Relative Error (RE) and\% Relative Standard Deviation (RSD) values, which are the indicators of intra-day as well as inter-day accuracy and precision of the results produced by the methods. Low values $(>2 \%)$ of both \%RE and \%RSD reflect the adequate accuracy and precision of the proposed methods.

\begin{tabular}{|c|c|c|}
\hline Parameter & BCG Method & BCP Method \\
\hline$\lambda_{\max }, \mathrm{nm}$ & 420 & 420 \\
\hline Colour stability & $60 \mathrm{~min}$ & $4 \mathrm{~h}$ \\
\hline Linear range, $\mu \mathrm{g} \mathrm{mL^{-1 }}$ & $1-20$ & $0.5-12$ \\
\hline Molar absorptivity $(\varepsilon), \mathrm{L} \mathrm{mol}^{-1} \mathrm{~cm}^{-1}$ & $1.79 \times 10^{4}$ & $3.09 \times 10^{4}$ \\
\hline Sandell sensitivity ${ }^{*}, \mu \mathrm{g} \mathrm{cm}^{-2}$ & 0.0179 & 0.0104 \\
\hline Limit of Detection (LOD), $\mu \mathrm{g} \mathrm{mL}^{-1}$ & 0.27 & 0.15 \\
\hline Limit of Quantification (LOQ), $\mu \mathrm{g} \mathrm{mL}^{-1}$ & 0.82 & 0.46 \\
\hline \multicolumn{3}{|l|}{ Regression equation, $Y^{* *}$} \\
\hline Intercept (a) & 0.0433 & 0.048 \\
\hline Slope (b) & 0.0412 & 0.0632 \\
\hline Standard deviation of a (Sa) & 0.0998 & 0.0988 \\
\hline Standard deviation of $b(\mathrm{Sb})$ & 0.0051 & 0.0080 \\
\hline Correlation coefficient (r) & 0.9992 & 0.9996 \\
\hline
\end{tabular}

*Limit of determination as the weight in $\mu \mathrm{g} \mathrm{mL}^{-1}$ of solution, which corresponds to an absorbance of $A=0.001$ measured in a cuvette of cross-sectional area 1 $\mathrm{cm}^{2}$ and $\mathrm{I}=1 \mathrm{~cm} .{ }^{* *} \mathrm{Y}=\mathrm{a}+\mathrm{bX}$, where $\mathrm{Y}$ is the absorbance, $\mathrm{X}$ concentration in $\mu \mathrm{g}$ $\mathrm{mL}^{-1}$, a intercept and b slope.

Table 1: Sensitivity and regression parameters.

\begin{tabular}{|c|c|c|c|c|c|c|c|}
\hline \multirow[t]{2}{*}{ Method } & \multirow{2}{*}{$\begin{array}{l}\text { CQB } \\
\left(\mu \mathrm{g} \mathrm{mL}^{-1}\right)\end{array}$} & \multicolumn{3}{|c|}{ Intra-day accuracy and precision $(n=7)$} & \multicolumn{3}{|c|}{ Inter-day accuracy and precision ( $n=7)$} \\
\hline & & $\begin{array}{l}\text { CQB found a }(\mu \mathrm{g} \\
\left.\mathrm{mL}^{-1}\right)\end{array}$ & RSDb\% & $\operatorname{Rec} \%$ & CQB found $\left(\mu \mathrm{g} \mathrm{mL}^{-1}\right)$ & RSDb\% & $\operatorname{Rec} \%$ \\
\hline \multirow[t]{3}{*}{ BCG } & 6.0 & 5.89 & 0.87 & 1.83 & 6.08 & 0.74 & 1.33 \\
\hline & 12.0 & 12.19 & 1.26 & 1.58 & 12.13 & 1.33 & 1.08 \\
\hline & 18.0 & 18.02 & 0.52 & 0.12 & 18.07 & 1.05 & 0.39 \\
\hline \multirow[t]{3}{*}{ BCP } & 3.0 & 2.96 & 0.89 & 1.33 & 2.95 & 1.83 & 1.67 \\
\hline & 6.0 & 5.96 & 1.56 & 0.67 & 6.02 & 1.36 & 0.34 \\
\hline & 9.0 & 9.14 & 0.67 & 1.56 & 8.94 & 0.67 & 0.33 \\
\hline
\end{tabular}

Table 2: Evaluation of intra-day and inter-day accuracy and precision. (a) Mean value of seven determination; (b) Relative standard deviation (\%); (c) Relative error (\%).

\section{Robustness and ruggedness}

Assay procedure was repeated after making small incremental variations in the optimized conditions such as, reagent volume, contact time, and wavelength, and the effect of these variations on assay results was investigated to assess the robustness of the methods. To evaluate ruggedness, determination was performed by a single analyst using three instruments in the same laboratory and also by three analysts using a single instrument. Each study was performed on three levels of analyte. The results of this study expressed as intermediate precision (\%RSD), which are $\leq 2.23 \%$ are compiled in Table 3, reveal that the performance of the method was unaffected by small variations in the optimized experimental variables, and instrument-to-instrument as well as analyst-to-analyst variations. 
Citation: Nagib Qarah AS, Basavaiah K, Swamy N (2017) Sensitive and Selective Extraction-Free Spectrophotometric Assay of Chloroquine Phosphate in Pharmaceuticals Based on Ion-Pair Reaction with Bromocresol Green and Bromocresol Purple. Pharm Anal Acta 8: 539. doi: $10.4172 / 2153-2435.1000539$

Page 6 of 9

\begin{tabular}{|c|c|c|c|c|c|c|}
\hline \multirow[t]{3}{*}{ Method } & \multirow{3}{*}{$\begin{array}{l}\text { CQB taken } \\
(\mu \mathrm{g} \mathrm{mL-1)}\end{array}$} & \multirow{2}{*}{\multicolumn{3}{|c|}{$\begin{array}{l}\text { Robustness } \\
\text { Parameters altered }^{*}\end{array}$}} & \multicolumn{2}{|l|}{ Ruggedness } \\
\hline & & & & & \multirow[t]{2}{*}{ Inter-analysts $(n=3)$} & \multirow{2}{*}{$\begin{array}{l}\text { Inter-instruments } \\
(n=3)\end{array}$} \\
\hline & & Volume of dye ${ }^{*}$ & Contact time ${ }^{* *}$ & $\lambda_{\max }, \mathrm{nm} \Psi$ & & \\
\hline \multirow[t]{3}{*}{ BCG } & 6.0 & 1.05 & 1.42 & 1.43 & 1.35 & 1.44 \\
\hline & 12.0 & 0.87 & 1.05 & 2.01 & 0.95 & 1.88 \\
\hline & 18.0 & 1.33 & 1.28 & 1.65 & 1.42 & 2.21 \\
\hline \multirow[t]{3}{*}{ BCP } & 3.0 & 1.53 & 1.51 & 1.61 & 1.24 & 2.23 \\
\hline & 6.0 & 1.12 & 1.35 & 1.55 & 0.66 & 1.68 \\
\hline & 9.0 & 1.29 & 0.86 & 0.96 & 1.26 & 2.04 \\
\hline
\end{tabular}

Table 3: Results of method robustness and ruggedness expressed as intermediate precision (\%RSD).

\section{Selectivity}

A systematic study was performed to determine the effect of additives by analyzing the placebo blank and synthetic mixture containing CQP. The absorbance of the placebo solution in each case was almost equal to the absorbance of the reagent blank which revealed no interference. When the methods were applied to determine CQP in the synthetic mixture, at 12 and $8 \mu \mathrm{g} \mathrm{mL}^{-1}$ CQB levels by BCG method and BCP method, respectively, percent recoveries of $97.58 \pm$ 1.65 and $96.46 \pm 1.56$ were realized, suggesting the selectivity of the methods proposed.

\section{Application to formulations}

The proposed methods were applied for the determination of CQB in tablet, injection and suspension and the results are presented in
Table 4 . The same batch formulations were subjected to the assay by the reference method. For parallel assay by the reference method [2] aqueous tablet extract or diluted injection solution was measured at $343 \mathrm{~nm}$. In the case of suspension, diluted suspension was filtered using a quantitative filter paper before recovering the absorbance and results were statistically evaluated by applying Student's t- and variance ratio F-test. The calculated $\mathrm{t}$ - and $\mathrm{F}$-values did not exceed the tabulated values at the $95 \%$ confidence level for four degrees of freedom, indicating agreeing accuracy and precision between the proposed methods and the reference method.

\begin{tabular}{|c|c|c|c|c|}
\hline \multirow[t]{3}{*}{ Formulation name } & \multirow[t]{3}{*}{ Nominal amount } & \multicolumn{3}{|c|}{ Found $^{*}(\%$ of nominal amount $\pm \mathrm{SD}$ ) } \\
\hline & & \multirow[t]{2}{*}{ Official method } & \multicolumn{2}{|l|}{ Proposed methods } \\
\hline & & & BCG Method BCP Method & \\
\hline \multirow[t]{3}{*}{ Cadiquin tablet } & \multirow[t]{3}{*}{$200 \mathrm{mg} /$ tablet } & \multirow[t]{3}{*}{$97.46 \pm 1.09$} & $98.89 \pm 1.35$ & $96.85 \pm 1.24$ \\
\hline & & & $t=2.24$ & $t=0.82$ \\
\hline & & & $F=1.37$ & $F=1.29$ \\
\hline \multirow[t]{3}{*}{ Maliago tablet } & \multirow[t]{3}{*}{$500 \mathrm{mg} / \mathrm{tablet}$} & \multirow[t]{3}{*}{$96.67 \pm 1.23$} & $95.96 \pm 0.88$ & $94.74 \pm 1.18$ \\
\hline & & & $t=1.05$ & $t=2.52$ \\
\hline & & & $F=1.95$ & $F=1.09$ \\
\hline \multirow[t]{3}{*}{ Cloquin injection } & \multirow[t]{3}{*}{$40 \mathrm{mg}$ per mL } & \multirow[t]{3}{*}{$101.4 \pm 1.22$} & $102.6 \pm 0.73$ & $100.8 \pm 1.33$ \\
\hline & & & $t=1.88$ & $\mathrm{t}=0.74$ \\
\hline & & & $F=2.79$ & $F=1.19$ \\
\hline \multirow[t]{2}{*}{ Emquin suspension } & \multirow{2}{*}{$100 \mathrm{mg}$ per $\mathrm{mL}$} & \multirow[t]{2}{*}{$97.36 \pm 1.44$} & $98.91 \pm 0.93$ & $99.28 \pm 1.02$ \\
\hline & & & $t=2.03$ & $\mathrm{t}=2.43$ \\
\hline
\end{tabular}


Citation: Nagib Qarah AS, Basavaiah K, Swamy N (2017) Sensitive and Selective Extraction-Free Spectrophotometric Assay of Chloroquine Phosphate in Pharmaceuticals Based on Ion-Pair Reaction with Bromocresol Green and Bromocresol Purple. Pharm Anal Acta 8: 539. doi: $10.4172 / 2153-2435.1000539$

Page 7 of 9

\begin{tabular}{|l|l|l|l|}
\hline & & F= 2.40 & F=1.99 \\
\hline *Mean value of five determinations. & \\
(Tabulated t-value at the $95 \%$ confidence level and for four degrees of freedom is 2.77). \\
(Tabulated F-value at the 95\% confidence level and for four degrees of freedom is 6.39).
\end{tabular}

Table 4: Results of analysis of formulations by the proposed methods and statistical comparison of the results with the official method

\section{Accuracy by recovery test}

Pre-analyzed tablet powder was spiked with pure CQP at three levels and the total was determined by the proposed methods. The determination each level was replicated thrice. The results of percent recovery of drug which reflect the accuracy are summarized in Table 5, and demonstrate the methods' freedom from interference by the coformulated substances in the tablets.

\begin{tabular}{|c|c|c|c|c|c|}
\hline Method & Tablet studied & $\begin{array}{l}\text { CQB in tablet, } \\
\mu \mathrm{g} \mathrm{mL}^{-1}\end{array}$ & $\begin{array}{l}\text { Pure CQB } \\
\text { added, } \\
\mu \mathrm{gL} \mathrm{m}^{-1}\end{array}$ & $\begin{array}{l}\text { Total found, } \\
\mu \mathrm{g} \mathrm{mL}^{-1}\end{array}$ & $\begin{array}{l}\text { Pure CQB recovered } \\
\text { Percent } \pm \text { SD* }^{*}\end{array}$ \\
\hline BCG & Cadiquin & $\begin{array}{l}5.93 \\
5.93 \\
5.93\end{array}$ & $\begin{array}{l}3.0 \\
6.0 \\
9.0\end{array}$ & $\begin{array}{l}8.65 \\
11.25 \\
14.28\end{array}$ & $\begin{array}{l}96.87 \pm 1.13 \\
94.32 \pm 0.65 \\
95.64 \pm 1.03\end{array}$ \\
\hline $\mathrm{BCP}$ & Cadiquin & $\begin{array}{l}2.91 \\
2.91 \\
2.91\end{array}$ & $\begin{array}{l}1.5 \\
3.0 \\
4.5\end{array}$ & $\begin{array}{l}4.55 \\
5.76 \\
7.67\end{array}$ & $\begin{array}{l}101.41 \pm 1.33 \\
97.36 \pm 0.85 \\
103.5 \pm 1.16\end{array}$ \\
\hline
\end{tabular}

Table 5: Results of recovery experiment through standard-addition method.

\section{Conclusion}

The proposed methods have the advantages of ease of performance, sensitivity as indicated by low LOD values and selectivity as shown by almost $100 \%$ recovery values. The methods are free from drastic experimental conditions unlike most of the available methods and simply involve mixing of the reactants followed by absorbance measurement. In contract to the current methods, the proposed methods are characterized by wide linear dynamic ranges enabling their application to samples of wide concentration ranges. The methods have been demonstrated to be both accurate and precise besides being robust and rugged as indicated by low values of relative error and relative standard deviation. Some of the advantageous features of the proposed methods in relation with the existing methods are summed up in Table 6. The main drawback of the methods is their inability to be applied to chloroquine phosphate directly and the need to convert the salt to base form, which of course, is one-step process. However, this limitation is outsmarted by multi-dimensional advantages of the recommended methods, and substantiates their usefulness in quality control laboratories.

\begin{tabular}{|c|c|c|c|c|c|c|}
\hline S. No & Reagent/s & Methodology & $\begin{array}{l}\text { Linear range }(\mu \mathrm{g} \\
\left.\mathrm{mL}^{-1}\right)\end{array}$ & LOD/LOQ $\left(\mu \mathrm{g} \mathrm{mL}^{-1}\right)$ & Remark & Ref. No. \\
\hline 1 & $\mathrm{BCP}$ & $\begin{array}{l}\text { lon-pair complex formed was } \\
\text { extracted in chloroform and } \\
\text { measured at } 420 \mathrm{~nm}\end{array}$ & $1.25-8.75$ & $0.128 / 0.428$ & $\begin{array}{l}\text { Extraction step, strict } \mathrm{pH} \\
\text { control }\end{array}$ & 34 \\
\hline 2 & $\mathrm{RB}$ & $\begin{array}{l}\text { lon-pair complex formed was } \\
\text { extracted in chloroform and } \\
\text { measured at } 420 \mathrm{~nm}\end{array}$ & - & - & - & 35 \\
\hline \multirow[t]{2}{*}{3} & BCG & \multirow{2}{*}{$\begin{array}{l}\text { lon-pair complex formed was } \\
\text { extracted in chloroform and } \\
\text { measured at } 420 \mathrm{~nm}\end{array}$} & \multirow{2}{*}{$50-250$} & \multirow{2}{*}{ - } & \multirow{2}{*}{$\begin{array}{l}\text { Extraction step, strict } \mathrm{pH} \\
\text { control }\end{array}$} & \multirow{2}{*}{36} \\
\hline & WTB & & & & & \\
\hline 4 & {$\left[\mathrm{Co}(\mathrm{SCN})_{4}\right]_{2-}$} & $\begin{array}{l}\text { lon-pair complex formed extracted } \\
\text { in nitrobenzene and measured at } \\
625 \mathrm{~nm}\end{array}$ & Feb-60 & - & $\begin{array}{l}\text { Extraction step, strict } \mathrm{pH} \\
\text { control }\end{array}$ & 37 \\
\hline
\end{tabular}


Citation: Nagib Qarah AS, Basavaiah K, Swamy N (2017) Sensitive and Selective Extraction-Free Spectrophotometric Assay of Chloroquine Phosphate in Pharmaceuticals Based on Ion-Pair Reaction with Bromocresol Green and Bromocresol Purple. Pharm Anal Acta 8: 539. doi: $10.4172 / 2153-2435.1000539$

Page 8 of 9

\begin{tabular}{|c|c|c|c|c|c|c|}
\hline 5 & {$\left[\mathrm{Mo}(\mathrm{SCN})_{6}\right]-$} & $\begin{array}{l}\text { lon-pair complex formed extracted } \\
\text { into methylene chloride and } \\
\text { measured at } 467 \mathrm{~nm}\end{array}$ & Feb-42 & - & Extraction step & 38 \\
\hline 6 & Chloranilic acid & CT complex measured at $520 \mathrm{~nm}$ & Aug-80 & _- & Less sensitive & 39 \\
\hline \multirow[b]{2}{*}{7} & $\mathrm{DDQ}$ & CT complex measured at $462 \mathrm{~nm}$ & May-53 & \multirow[b]{2}{*}{-} & Moderated sensitive & \multirow[b]{2}{*}{40} \\
\hline & 12 & CT complex measured at $293 \mathrm{~nm}$ & 15-Jan & & $\begin{array}{l}\text { Measurement at lower } \\
\text { analytical wavelength }\end{array}$ & \\
\hline 8 & $\mathrm{KBrO}_{3}-\mathrm{KBr}$ & $\begin{array}{l}\text { Brominated product in acidic } \\
\text { medium measured at } 350 \mathrm{~nm}\end{array}$ & $40-200$ & - & $\begin{array}{l}\text { Longer reaction time, less } \\
\text { sensitive }\end{array}$ & 41 \\
\hline 9 & $\begin{array}{l}\mathrm{Fe}(\mathrm{III})-1,10 \\
\text { phenanthroline }\end{array}$ & $\begin{array}{l}\text { Complex product colored } \\
\text { measured at } 510 \mathrm{~nm}\end{array}$ & $20-320$ & - & Less sensitive & 42 \\
\hline \multirow{2}{*}{10} & $\mathrm{KBrO3}$ & \multirow{2}{*}{$\begin{array}{l}\text { Recorded the absorbance change } \\
\text { with time at } 343 \mathrm{~nm}\end{array}$} & \multirow{2}{*}{$0.5-5$} & \multirow{2}{*}{0.06} & \multirow{2}{*}{$\begin{array}{l}\text { Critical dependent on } \\
\text { experimental variables }\end{array}$} & \multirow{2}{*}{43} \\
\hline & Kinetic & & & & & \\
\hline \multirow{2}{*}{11} & \multirow{2}{*}{$\mathrm{BCG} / \mathrm{BCP}$} & \multirow{2}{*}{$\begin{array}{l}\text { Yellow ion-pair complex formed in } \\
\text { chloroform measured at } 420 \mathrm{~nm}\end{array}$} & 20-Jan & $0.27 / 0.82$ & \multirow{2}{*}{$\begin{array}{l}\text { No drastic experimental } \\
\text { conditions, no extraction } \\
\text { step, instantaneous } \\
\text { reaction, more sensitive. }\end{array}$} & \multirow{2}{*}{ Present methods } \\
\hline & & & $0.5-12$ & $0.15 / 0.46$ & & \\
\hline
\end{tabular}

Table 6: Comparison of the proposed and the existing methods. BCP: Bromocresol Purple; BCG: Bromocresol Green; RP: Rose Bengal; DDQ: Dichloro-Dicyano-p-Benzoquinone.

\section{Acknowledgements}

The authors thank Cipla India Ltd., Mumbai, India for gifting pure chloroquine phosphate sample. Prof. K. Basavaiah thanks the University Grants Commission, New Delhi, India, for financial assistance in the form BSR faculty fellowship.

\section{Declaration of Interest}

The authors report no declarations of interest.

\section{References}

1. (2006) An Encyclopaedia of Chemicals, Drugs and Biologicals (14th edn.). White House Station, Merck index, p: 358.

2. United States Pharmacopeia (2007) 30-NF25. United States Pharmacopeial Convention. Inc. Rockville, p: 1722-1723.

3. Gennaro AR (2000) Remaington: the science and practice of pharmacy (20th edn.). Lippincott Williams and Wilkins, p: 1547.

4. Mukhija S, Talegoankar J, Bopari KS (1982) Alkalimetric determination of chloroquine salts. Indian Drug 20: 30-32.

5. Parimoo P, Bammeke AO (1981) Application of ion-exchange technique in the analysis of syrup of chloroquine phosphate. Negerian J Pharm 12: 373-376.

6. Midala TAS, Timothy SY, Emenike IV, Midala J (2016) Quality assurance testing of chloroquine tablets in northern Nigeria. Inter J Pharm Pharm Res 6: 297-303.

7. Bhanumathi ML, Wadodkar SG, Kasture AV (1980) Methods for chloroquine phosphate. Indian Drug 17: 304-306.

8. Saad B, Zin ZM, Jab MS, Rahman IA, Saleh MI, et al. (2005) Flowthrough chloroquine sensor and its applications in pharmaceutical analysis. Anal Sci 21: 521-524.

9. Saad B, Kanapathy K, Ahmed MN, Hussin AH, Ismail Z (1991) Chloroquine polymeric membrane electrodes: development and applications. Talanta 38: 1399-1402.
10. Hassan SSM, Ahmed MA (1991) Polyvinyl chloride matrix membrane electrodes for manual and flow injection analysis of chloroquine in pharmaceutical preparations. J Asso Offi Anal Chem 74: 900-905.

11. Cosofret VV, Buck RP (1985) Achloroquine membrane electrode with low detection limit. Anal Chim Acta 174: 299-303.

12. Nelson O, Olajire A, Ayodeji A (2010) Rapid spectrofluorimetric determination of chloroquine phosphate tablets. Inter J Drug Develop Res 2: 412-417.

13. Liang YD, Song JF, Yang XF, Guo W (2004) Flow-injection chemiluminescence determination of chloroquine using peroxynitrus acid as oxidant. Talanta 62: 757-763.

14. Amador-Hernandez J, Fernandez-Romero JM, Luque de Castro MD (2001) Continuous determination of chloroquine in plasma by laserinduced photochemical reaction and fluorescence. J Anal Chem 369: 438-441.

15. Lukasiewicz RJ, Fitzgerald JM (1974) Comparison of three photochemical-fluorimetric methods for determination of chloroquine. Applied Spectro 28: 151-155.

16. Jan MR, Shah J, Javed MA, Yousaf N (2014) Micelle based spectrofluorimetric determination of chloroquine phosphate in commercial formulation and human plasma. Tenside Surfactants Detergents 51: 491-496.

17. Mahajan PG, Desai NK, Dalavi DK, Bhopate DP, Kolekar GB, et al. (2015) Cetyltrimethylammonium bromide capped 9-anthraaldehyde nanoparticles for recognition of phosphate anion in aqueous solution based on fluorescence quenching for analysis of chloroquine. J Fluores 25: 31-38.

18. Aitha VL (2013) Spectrophotometric method for estimation of chloroquine in bulk and tablet dosage form. Asian J Pharm Clin Res 6: 156-158.

19. Raghuveer S, Srivastava CMR, Vatsa DK (1991) Spectrophotometric determination of chloroquine phosphate in dosage forms. Indian Drug 29: 134-136.

20. Singh V, Mahanwal JS, Shukla SK (1990) Chloroquine poisoning-analysis by derivative uv-spectrophotometry. Indian J Forensic Sci 4: 183-189.

21. Siham A, Kamal EE, Magga MEM, Ishraqa M (2016) Application of derivative spectrophotometric for analysis of chloroquine phosphate dosage form. British J Pharm Res 12: 1-9. 
Citation: Nagib Qarah AS, Basavaiah K, Swamy N (2017) Sensitive and Selective Extraction-Free Spectrophotometric Assay of Chloroquine Phosphate in Pharmaceuticals Based on Ion-Pair Reaction with Bromocresol Green and Bromocresol Purple. Pharm Anal Acta 8: 539. doi: $10.4172 / 2153-2435.1000539$

Page 9 of 9

22. Lawal A, Umar RA, Abubakar MG, Faruk UZ (2012) Development and validation of uv-spectrophotometric and HPLC methods for quantitative determination of chloroquine and amodiaquine in pharmaceutical formulations. Inter J Chem Tech Res 4: 669-676.

23. Rivas-Granizo P, Jorge Santos SRC, Ferraz HG (2009) Development of a stability-indicating LC assay method for determination of chloroquine. Chromatographia 69: 137-141.

24. Daneshfar A, Khezeli T, Manafi MH (2009) Determination of antimalaria agent chloroquine using single drop liquid-liquid-liquid micro extraction. J Separation Sci 32: 511-516.

25. Samanidou VF, Evaggelopolou EN, Papadoyannis IN (2004) Simultaneous determination of monodesethylchloroquine, chloroquine, cycloguanil and proguanil on dried blood spots by reverse-phase liquid chromatography. J Pharm Bio Anal 38: 21-28.

26. Dwivedi AK, Saxena D, Singh S (2003) HPLC and HPTLC assays for the antimalarial agents chloroquine, primaquine and bulaquine. J Pharm Biomed Anal 33: 851-858.

27. Paci A, Caire-Maurisier AM, Rieutord A, Brion F, Clair P (2002) Dualmode gradient HPLC procedure for the simultaneous determination of chloroquine and proguanil. J Pharm Biomed Anal 27: 1-7.

28. Karim Elfatih IA, Ibrahim KEE, Abdelrahman AN, Fell AF (1994) Photo degradation studies on chloroquine phosphate by high performance liquid chromatography. J Pharm Biomed Anal 12: 667-674.

29. Abdelrahman AN, KarimElfatih IA, Ibrahim KEE (1994) Determination of chloroquine and its decomposition product in various brands of different dosage forms by liquid chromatography. J Pharm Biomed Anal 12: 205-208.

30. Ramana RG, Raghuveer S, Prasad V (2006) High performance liquid chromatographic determination of chloroquine phosphate in dosage forms. Indian Drugs 23: 555-558.

31. Das Gupta V (1986) Quantitation of chloroquine phosphate and primaquine phosphate in tablets using high performance liquid chromatography. Anal Lett 19: 1523-1532.

32. Karuppiah SP, Anver Basha K (2014) Analytical method development for impurities present in hydroxyl chloroquine phosphate from antimalarial tablet formulation. J Pharm Pharm Sci 3: 1556-1567.

33. Khalil IF, Alifrangis M, Michael RC, Hoegberg LC, Ronn A, et al. (2011) Development of ELISA-based methods to measure the anti-malarial drug chloroquine in plasma and in pharmaceutical formulations. Malaria J 10: 249.

34. Nagaraja P, Shrestha AK, Shivakumar A, Gowda AK (2010) Spectrophotometric determination of chloroquine, pyrimethamine and trimethoprim by ion-pair extraction in pharmaceutical formulation and urine. J Food Drug Anal 18: 239-248.

35. Abdel-Gawad FM (1994) Spectrophotometric determination of trace amounts of chloroquine phosphate and mebeverine hydrochloride by ion-pair extraction with Rose Bengal. Egyptian J Anal Chem 3: 129-134.

36. Lakshmi AV (2013) Spectrophotometric determination of chloroquine in bulk and pharmaceutical formulations. Inter J Res Pharm Sci 4: 361-365.
37. Onyegbule FA, Adelusi SA, Onyegbule CE (2011) Extractive visible spectrophotometric determination of chloroquine in pharmaceutical and biological materials. Inter J Pharm Sci Res 2: 72-76.

38. Khalil SM, Mohamed GG, Zayed MA, Elqudaby HM (2000) Spectrophotometric determination of chloroquine and pyrimethamine through ion-pair formation with molybdenum and thiocyanate. Microchem J 64: 181-186.

39. Ofokansi KC, Omeje EO, Emeneka CO (2009) Spectroscopic studies of the electron donor-acceptor interaction of chloroquine phosphate with chloranilic acid. Tropical J Pharm Res 8: 87-94.

40. Zayed MA, Khalil SM, Elqudaby HM (2005) Spectrophotometric study of the reaction mechanism between DDQ-л and iodine $\sigma$-acceptors and chloroquine and pyrimethamine drugs and their determination in pure and in dosage forms. Spectrochim Acta, Part A: Mol Biomol Spectro 62: 461-465.

41. Raddy NR, Prabhavathi K, Chakravarthy IE (2004) A new spectrophotometric estimation of chloroquine phosphate from tablets. Indian J Pharm Sci 66: 240-242.

42. Karad MD, Barhate VD (2015) Spectrophotometric determination of an antimalarial drug in bulk and pharmaceutical formulations. Inter J Current Pharm Res 7: 27-29.

43. Mohamed AA (2009) Kinetic spectrophotometric determination of amodiaquine and chloroquine. Monatsh Chem 140: 9-14.

44. (2005) International Conference on Hormonisation of Technical Requirement for Registration of Pharmaceuticals for Human Use, ICH Harmonised Tripartite Guideline, Validation of Analytical Procedures: Text and Methodology Q2(R1), London.

45. Higuchi T, Brochmann-Hanssen E (1961) Pharmaceutical analysis, Interscience, New York, pp: 413-418.

46. Basavaiah K, Sameer AMA, Vinay KB (2009) Simple and sensitive spectrophotometric determination of olanzapine in pharmaceutical formulations using two sulphonphthalein dyes. J Food Drug Anal 17: 434-442.

47. Al-Gannam SM (2006) A simple spectrophotometric method for the determination of beta-blockers in dosage forms. J Pharm Biomed Anal 40: 151-156.

48. Abdine H, Belal F, Zoman N (2002) Simple spectrophotometric determination of cinnarizine in its dosage forms. Farmaco 57: 267-271.

49. Manjunatha DH, Skaikh SMT, Harikrishna K, Sudhirkumar R, Kandagal PB (2008) Simple and sensitive spectrophotometric methods for the determination of acebutolol hydrochloride in bulk sample and pharmaceutical preparations. Eclet Quim 33: 37-40.

50. Abdine HH (2000) Spectrophotometric determination of cisapride using some sulphophthalein dyes. Alex J Pharm Sci 14: 75-78.

51. Vinay KB, Revannasiddappa HD, Basavaiah K (2011) Sensitive and extraction-free spectrophotometric determination of lamotrigine in pharmaceuticals using two sulphophthalein dyes. Thai J Pharm Sci 35: 65-76. 